\title{
PERADABAN ISLAM: HEGEMONI DAN KONTRIBUSINYA DI BIDANG SASTRA ARAB
}

\author{
Abdul Latif \\ Institut Agama Islam Negeri Metro \\ elmoffats@gmail.com
}

\begin{abstract}
Islamic Civilization is one of civilizations which has a prominent role in the world civilizations history. But many bad stereotypes has been given by Orientalist about Islamic Civilization. More than it, some of them also regard that Islamic Civilization has the lowest contribution in human civilization advancement. To know how Islamic Civilization ruled and had a role in developing civilization in that time, so the writer uses hegemony theory of Antonio Gramsci. The result of this research proves that there are two ways done by Islamic Civilization in ruling the society under its authority, first is by structured leadership led by the highest commander in Islam society civilization, and second is by morality leadership which that moral is taken from Alquran principals and values. Despite opinions above, Islamic Civilization contributions also has been acknowledged by European especially in this three sectors, it is in science, morality and thought. The contribution of Islamic civilization in the field of Arabic Literature is the presence of themes of heroism and the spirit of struggle in European literary works.
\end{abstract}

Keywords: Islamic Civilization, Hegemony, Contribution

\begin{abstract}
Abstrak
Peradaban Islam merupakan salah satu peradaban yang paling berperan dalam sejarah peradaban-peradaban yang pernah ada di dunia. Namun, tidak sedikit stereotip buruk diberikan oleh para Orientalis mengenai peradaban Islam. Bahkan, ada sebagian Orientalis yang beranggapan bahwa peradaban Islam merupakan peradaban yang paling sedikit memberikan kontribusinya dalam kemajuan peradaban umat manusia. Untuk mengetahui bagaimanakah peradaban Islam berkuasa dan berperan dalam memajukan peradaban saat itu, maka penulis menggunakan teori hegemoni Antonio Gramsci. Hasil penelitian ini membuktikan bahwa ada dua cara yang dilakukan peradaban Islam dalam menghegemoni masyarakat yang ada di bawah kekuasaannya, yaitu dengan kepemimpinan terstruktur yang dikomandoi oleh pemimpin tertinggi dalam peradaban umat Islam, dan dengan kepemimpinan bermoral, yang mana moral tersebut diambil berdasarkan nilai-nilai dan prinsip-prinsip Alquran. Adapun kontribusi peradaban Islam yang juga diakui oleh bangsa Eropa mencakup tiga hal pokok, yaitu kontribusi peradaban Islam dalam bidang ilmu pengetahuan, dalam bidang moral, dan dalam bidang pemikiran. Adapun kontribusi peradaban Islam dalam bidang Sastra Arab ialah hadirnya tema-tema kepahlawanan dan semangat perjuangan dalam karya sastra bangsa Eropa.
\end{abstract}

Kata Kunci: Peradaban Islam; Hegemoni; Kontribusi. 


\section{Pendahuluan}

Agama dan negara merupakan dua hal yang tidak bisa dipisahkan dalam upaya mewujudkan masyarakat madani. Karena sejatinya, agama tidak akan bisa berkembang dengan sempurna apabila negara yang menaunginya tidak memberikan ruang untuk keberlangsungan kegiatan agama tersebut. Sebagai buktinya, Agama Islam sebelum Fath\}ul Makkah (pembebasan kota Mekah) merupakan agama yang tidak bisa berkembang seutuhnya. Hal ini dikarenakan dominasi kelompok pembesar suku Quraisy yang tidak mengizinkan islam berkembang di negara mereka.

Negara pun demikian halnya. Sebagai contoh, jepang misalnya. Jepang yang saat ini bisa dibilang sebagai negara yang maju dalam segi ekonomi, namun mayoritas masyarakatnya masih dalam ambang kemiskinan, sehingga tak ayal kejahatan di jepang seperti: pemerkosaan, pencabulan, pencurian, dan segala kejahatan nista lainnya masih merajalela di jepang. Hal ini terjadi disebabkan karena Negara Jepang tidak memiliki nilai-nilai agama yang utuh untuk mengatur moral-moral hukum yang berlaku di sana.

Agama dan negara memang merupakan dua hal yang bisa dibilang sulit untuk disatukan seutuhnya. Karena apabila suatu negara didominasi oleh agama tertentu, maka sebisa mungkin agama yang dominan tersebut mempertahankan ideologinya untuk mempertahankan dominasinya terhadap negara. Begitupun sebaliknya, apabila negara lebih dominan terhadap agama di dalam suatu pemerintahan, maka sekuat mungkin negara tersebut mendominasi agama agar pemerintahan tetap utuh berada di bawah kekuasan negara.

Peradaban Islam merupakan merupakan contoh dari sebuah negara dan agama yang bisa disatukan seutuhnya. Meskipun banyak dari kalangan Orientalis yang mencibir akan masa kejayaan peradaban islam tersebut. Menurut mereka, peradaban Islam merupakan peradaban yang miskin, baik dari segi ekonomi, budaya, dan lain-lain. ${ }^{1}$ Hal ini tentu menimbulkan problem tersendiri, karena bagaimana mungkin agama (Islam) dan negara yang telah bersatu seutuhnya bisa mewujudkan peradaban yang ideal, sedangkan dari pihak lain masih banyak yang melontarkankan cibiran akan ketidakselarasan dalam peradaban Islam saat itu.

Jika memang pada sejarahnya, agama dan negara berhasil disatukan dalam upaya pembentukan masyarakat madani. Namun, masih ada pihak lain yang mencibir akan keselarasan agama dan negara dalam peradaban tersebut, tentu sebenarnya ada pandangan yang keliru dalam menilai pemerintahan yang sedang

${ }^{1}$ Edward W.Said, Orientalisme, terj. Achmad Fawid (Yogyakarta: Pustaka Pelajar, cet II, 2016), h. 472 
berkuasa. Pandangan yang keliru terhadap kekuasaan peradaban yang sedang berkuasa ini sering disebut (disamakan) dengan dominasi. Namun sebenarnya pandangan ini memiliki makna dan tata cara kerja yang lebih halus daripada dominasi. Pandangan ini ialah Hegemoni.

Hegemoni diperkenalkan oleh Antonio Gramsci saat ia menulis tentang catatancatatan tentang perjuang revolusinya di dalam penjara. Dari catatan-catatan tersebut terciptalah konsep hegemoni yang sampai sekarang masih digunakan para pakar Sosialis untuk mengkritisi sebuah pemerintahan dalam suatu negara.

Teori hegemoni yang akan dibahas pada tulisan ini bukan hanya teori hegemoni Gramsci, akan tetapi tulisan ini juga akan membahas sedikit tentang teori hegemoni Laclau dan Mouffe. Selanjutnya, tulisan ini akan sedikit membahas tentang hegemoni Islam dalam menguasai peradaban, serta kontribusi peradaban Islam untuk dunia.

\section{Sekilas tentang Teori Hegemoni}

\section{Teori Hegemoni Antonio Gramsci}

Gramsci memiliki nama lengkap Antonio Gramsci. Ia lahir dan dibesarkan dri keluarga yang kurang mampu, sehingga ia sangat peka dalam fenomena sosila yang terjdi di sekitarnya. Gramsci menghabiskan jatah umurnya selama 46 tahun mulai dari tahun 1891 sampai 1937 di Italia.
Jatah umur Gramsci yang hanya 46 tahun tersebut terbagi dalam lima fase ${ }^{2}$ :

a. Masa kecil sampai masa remaja di Sardinia (1891-1911).

b. Masa studinya di Turin, dan awal karirnya sebagai editor di majalah milik Partai Sosialis Grido Popolo (1911-1918).

c. Masa berkarir sebagai redaktur di L'Ordine Nuovo (1918-1920).

d. Masa berkarir di partai komunis Italia PCI (1921-1926).

e. Masa berkarir di penjara (1926-1937) .

Berdasarkan lima fase kehidupan yang dilalui Gramsci di atas, maka dapat disimpulkan bahwa seluruh kehidupan Gramsci ia perjuangkan untuk membela kaum proletar (buruh) yang tertindas. Perjuangannya tersebut ia lakukan secara aktif dan pasif. Perjuangan yang aktif ia lakukan saat ia menjabat sebagai pimpinan partai komunis Italia PCI. Dan perjuangan pasifnya ia jalani saat ia mengkiritik pemerintahan melalui majalah yang ia pimpin yaitu L'Ordine Nuovo.

Akhir dari perjuangan Gramsci ditorehkan dalam beberapa karya yang ia tuangkan dalam beberapa karya tulisnya di bawah ini ${ }^{3}$ :

a. History, Philosophy and Culture in the Young Gramsci, editor P. Calvcanti dn

\footnotetext{
${ }^{2}$ Nezar Patria dan Andi Arief, Antonio Gramsci Negara dan Hegemoni, (Yogyakarta: Pustaka Pelajar, cet III, 2009), h. 40-41.

${ }^{3}$ Ibid., h. 55.
} 
P. Piccone diterbitkan di St Louis (1975)

b. Letter from Prison, New York, 1973.

c. New Edinburgh Review, Three Special Gramsci issues, 1974.

d. Selection from Cultural Writing, ed. David Forgacs and Geoffey Nowell Smith, London, 1957.

e. The Modern Prince and Other Political Writings, ed. Louis Marks, London, 1957

f. Selection from Political Writings: 19101920, London, 1977.

g. Selection from Political Writings: 19211926, London, 1978.

h. Selection from the Prison Notebooks, ed. Q.Hoare and G.Nowell Smith, London, 1971.

Konsep Hegemoni sejatinya telah ada sebelum masa Gramsci. Jadi, Gramsci bukanlah orang pertama yang mencentuskan teori hegemoni. Secara historis, konsep hegemoni pertama kali diperkenalkan oleh seorang Marxis Rusia yang bernama Plekanov pada tahun $1880 .{ }^{4}$ Konsep hegemoni Plekanov hadir sebagai strategi untuk menjatuhkan pemerintahan. Singkatnya, konsep hegemoni Plekanov merupakan sebuah kepemimpinan hegemonik proletariat yang diusung oleh perwakilan-perwakilan berbagai lapisan masyarakat yang memiliki tujuan yang sama untuk menjatuhkan pemerintahan yang ada.

${ }^{4}$ Robert Bockock, Hegemony, (London: Tavistock Publication,1986), h. 24.
Selain Plekanov, Lenin merupakan salah satu tokoh dalam teori hegemoni. Hegemoni menurut Lenin ialah adanya peran kepemimpinan teoritis yang bergerak secara konkret, dan dimanifestasikan dalam sebuah partai pelopor. ${ }^{5}$ Berdasarkan dari ide tentang hegemoni yang dicetuskan oleh kedua pelopor hegemoni di atas, yaitu Pelakanov dan Lenin, maka hegemoni Gramsci lebih cenderung memiliki kesamaan dengan konsep hegemoni Lenin, yaitu dalam adanya peran kepemimpinan.

Gramsci menjelaskan tentang bagaimana konsep hegemoni yang ia idamkan dalam bukunya 'Selections from the prison notebooks' seperti di bawah ini:

'A sosial group can, indeed must, already exercise 'leadership' before winning governmental power (this indeed is one of the principal conditions for the winning of such power); its subsequently becomes dominant when it exercises power, but even if its holds it firmly in its grasp, it must continue to 'lead' as well ${ }^{6}$

Kesimpulan dari pendapat Gramsci di atas mengenai hegemoni yang ideal ialah sebuah dominasi yang dilakukan oleh kelas sosial terhadap pemerintahan yang berkuasa harus berdasarkan kepemimpinan intelektual dan moral, bukan berdasarkan

${ }^{5}$ Nezar Patria dan Andi Arief, Antonio Gramsci Negara dan Hegemoni, h.117.

${ }^{6}$ Antonio Gramsci, Selections From the Prison Notebooks, (ed.) Quintin Hoare dan Nowell Smith, (New York: International Publishers, 1976), h. 57-58. 
gerakan dominasi yang penuh kekerasan dan penindasan. Hal ini karena, hegemoni yang disalurkan melalui ideologi-ideologi dalam bingkai kepemimpinan intelektual dan moral akan lebih tuntas dampak hegemoninya dalam suatu pemerintahan. Namun, untuk menyalurkan ideologi-ideologi yang ada dari berbagai kelas sosial, tentu diperlukan konsensus. Konsensus sendiri merupakan titik tolak hegemoni. Konsensus dapat terlaksana dengan baik jika para perwakilan dari kelas sosial yang ada bisa menselaraskan persepsi ideologi-ideologi mereka untuk melakukan hegemoni.

Singkatnya, hegemoni merupakan konsep kepemimpinan yang berdasarkan strategi dan ideologi sudah siap secara teoritis, sehingga bisa konsisten untuk diterapkan untuk memimpin suatu Negara. Konsep hegemoni dalam pengertian Gramsci tersebut ia hasilkan dari pengalamannya sebagai seorang revolusioner yang berhasil menggerakkan perlawanan kelas buruh proletar di Italia untuk menggoyahkan kepemimpinan kaum borjuis di Italia saat itu.

Teori hegemoni Gramsci bisa digolongkan sebagai teori hegemoni yang mapan dan ideal. Karena, Gramsci sendirilah yang mempraktekkan konsep teori hegemoninya untuk menyadarkan kelas buruh proletariat akan dominasi kelas borjuis yang selama itu lebih dominan atas kelas buruh.
Teori hegemoni Gramsci berhasil dan sukses diterapkan dengan berdirinya partai komunis (PCI) yang ia dirikan untuk mengulingkan pemerintah yang ada saat itu. Akan tetapi, saat Gramsci berhasil menggulingkan pemerintahan yang ada, justru terjadi dominasi internal antara pihak internal partai komunis PCI yang sempat ia pimpin. Hal itu disebabkan adanya sikap yang berlawanan antara Gramsci dan Bordiga dalam munculnya kekuatan fasisme di Italia. Meskipun keduanya sama-sama mendirikan PCI, keduanya memiliki pendapat yang berbeda. Bordigo menganggap Fasisme hanyalah sebatas gerakan politik dari kaum borjuis yang tidak berbahaya secara politik. Sedangkan Gramsci menganggap Fasisme tidak hanya mengancam gerakan komunis di Italia, bahkan, ia yakin bahwa fasisme cenderung untuk berkuasa. ${ }^{7}$

\section{Teori Hegemoni Laclau dan Mouffe}

Ernesto Laclau merupakan seorang profesor teori politik di Universitas Essex. Sumbangsihnya dalam bidang disiplin ilmu sosial dan politik cukup signifikan. Hal itu ia buktikan dengan berbagai karyanya. Di antara karyanya ialah; Politics and Ideology in Marxist Theory, New Reflection on the Revolution of Our Time, The Making of Making Political Identities,

7 Nezar Patria dan Andi Arief, Antonio Gramsci Negara dan Hegemoni, h. 50 
Contingency, hegemony, Universality. ${ }^{8}$

Chantal mouffe memiliki kesamaan profesi dan konsentrasi studi dengan Laclau. Chantal Mouffe juga merupakan seorang profesor di bidang teori politik di pusat studi demokrasi Universitas Westminter. Adapun di antara karyanya adalah Among Other Works, The Return of The Political, The Dimensions of Radical Democracy, The Challenge of Carl Schmitt, dan The Democratical Pardox. ${ }^{9}$

Karya monumental Ernest Laclau dan Chantal Mouffe ialah Hegemony and Sosialist Strategy: Towards A Radical and Democratic Politics, yang diterbitkan pertama kali pada tahun 1985. Karya inilah yang membuat keduanya mempunyai andil besar dalam konsep hegemoni.

Konsep hegemoni Laclau dan Mouffe tidak jauh berbeda. Karena, Laclau sendiri dengan jelas menyatakan bahwa analisis yang paling utama untuk menganalisis politik ialah konsep hegemoninya Gramsci. ${ }^{10}$ Kecondongan bahwa konsep hegemoni Laclau dan Mouffe bermuara pada konsep hegemoninya Gramsci dapat dilihat dari kutipan di bawah ini:

"The concept of hegemony as it emerged in Russian Sosial Democracy-

${ }^{8}$ Laclau, Ernesto and Chantal Mouffe, Hegemony and Sosialist Strategy: Towards A Radical Democratic Politics, (London: Verso, Second Edition, 2001), h. cover belakang.

${ }^{9}$ Ibid., h. cover belakang.

${ }^{10}$ Ernesto Laclau, "Democracy and the Question of Power", Dalam Jurnal Constellations, vol.VII, nomor 2, 2001, h. 5 which, as we shall see, also supposed a logic of contingency - was from this point of view much less radical. Neither Lenin nor Trotsky was capable questioning the necessity for sosial agents to have a class character. Only with Gramsci did the two traditions converge in his concept of 'historical bloc', where the concept of hegemony derived from Leninism meets in a new synthesis with the concept of 'bloc' derived from Sorel." $" 11$

Meskipun demikian, konsep hegemoni Laclau dan Mouffe memiliki perbedaan dalam hal inovasi dari konsep hegemoni yang dicetuskan oleh Antonio Gramsci. Inovasi yang mereka berdua lakukan dalam konsep hegemoni sematamata agar konsep hegemoni lebih aplikatif untuk merespon krisis sosial di abad modern ini. Hal ini dapat lebih jelas kita lihat dalam buku masterpiece mereka berdua di bawah ini:

"The concept of hegemony did not emerge to define a new type of relation in its specific identity, but to fill a hiatus that had opened in the chain of historical necessity. 'Hegemony' will allude to an absent totality, and to diverse attempts at recomposition and rearticulation which, in overcoming this original absence, made it possible for struggles to be given a

\footnotetext{
${ }^{11}$ Laclau, Ernesto and Chantal Mouffe, Hegemony and Sosialist Strategy: Towards A Radical Democratic Politics, h. 42
} 
meaning and for historical forces to be endowed with full positivity. The contexts in which the concepts appear will be those of a fault (in the geological sense), of a fissure that had to be filled up, of a contingency that had to be overcome. 'Hegemony' will be not the majestic unfolding of an identity but the response to a crisis." 12

Inovasi dari konsep hegemoni Laclau dan Mouffe terletak pada objek hegemoni. Jika pada konsep hegemoni Gramsci objek hegemoninya adalah kelas sosial, khususnya kelasa buruh. Maka, objek dari konsep hegemoni Laclau dan Mouffe ialah analisis wacana (Discourse analysis). Wacana yang dimaksud di sini ialah segala bentuk wacana (berita) yang sedang booming di suatu Negara. Jadi, objek hegemoni dalam teori Laclau dan Mouffe lebih luas dari pada konsep hegemoni Gramsci.

Analisis wacana dalam hegemoni Laclau dan Mouffe mulai dicanangkan semenjak adanya keterbatasan objek sosial, khususnya golongan proletar (buruh), maka anatagonisme konsep hegemoni Laclau dan Mouffe lebih terfokus terhadap analisis waacana. Karena di dunia modern buruh sudah tidak menjadi hal yang relevan sebagai objek hegemoni. Disebabkan karena hegemoni yang terjadi di zaman modern ini lebih canggih dan sunyi, yaitu melalui wacana.

\footnotetext{
${ }^{12}$ Ibid., h. 7
}

Hampir di setiap kelas sosial pada era modern ini terhegemoni dengan wacana-wacana ideologi pemerintah yang berkuasa. Hegemoni yang dilakukan oleh pemerintahan yang berkuasa tersebar dengan mudah dan tanpa terasa melalui media elektronik, maupun media cetak. Namun, untuk menyadari masyarakat bahwa mereka sedang terhegemoni, harus dibutuhkan metode khusus.

Metode khusus inilah yang disebut sebagai antagonisme oleh Laclau dan Mouffe dalam konsep hegemoninya. Menurut mereka berdua antogonisme merupakan 'a failure of difference' semenjak terjadi keterbatasan dalam objektivitas sosial. Untuk lebih jelas memahami antagonisme sosial yang mereka berdua maksudkan, maka kita lihat kutipan di bawah ini:

" a result of the exclusion of discursive elements, the differential character of which is collapsed through their articulation in a chain of equivalence". ${ }^{13}$

Antagonisme sosial menjadi hal yang penting dalam teori wacana Laclau dan Mouffe karena, antagonisme sosial memainkan peran penting untuk menciptakan (memunculkan) bentuk hegemoni yang ada dalam suatu pemerintahan.

13 Jacob Torfing, New Theories Of Discourse: Laclau, Mouffe, Zizek, (Oxford: Blackwell, 1999), h. 305 
Jika antagonisme sosial telah terkuak, maka teori hegemoni Laclau dan Mouffe sangat relevan untuk diterapkan. Saking pentingnya antagonisme sosial dalam teori hegemoni Lclau dan Mouffe, maka antagonisme sosial bisa diibaratkan seperti kunci untuk memasuki pintu konsep hegemoni Laclau dan Mouffe.

Salah satu contoh antagonisme sosial adalah adanya waktu luang, budaya, seks, kematian dan lain-lain. Formasi sosial tersebutlah yang akan melahirkan antagonisme-antagonisme sosial yang baru.

Dari antagonisme-antagonisme sosial yang baru itulah nantinya akan muncul, agen-agen gerakan sosial yang baru. Agen sosial yang lebih kompleks ketimbang agen sosial yang ada pada zaman Gramsci. Agen sosisal ini juga serig disebut sebagai agen sosial Post Marxisme.

Untuk menghadapi gerakan-gerakan sosial yang baru tersebut Laclau dan Mouffe menawarkan rekonstruksi universalitas terhadap identitas dan tuntutan.

\section{Hegemoni Peradaban Islam}

Hegemoni peradaban Islam berada di puncak kejayaanya pada tahun VIII sampai XI di bawah kepemimpinan Dinasti Abbasiyah. ${ }^{14}$ Namun, yang penulis maksudkan dalam tulisan ini ialah hegemoni peradaban Islam dari masa kejayaan Islam sebagai negara yang dimulai dari masa

\footnotetext{
${ }^{14}$ Edward W.Said, Orientalisme, h. 472
}

Muhammad saw. sampai runtuhnya peradaban Islam sebagai negara pada peristiwa jatuhnya kerajaan Turki Utsmani.

Islam sebagai negara yang dominan memiliki setidaknya dua cara untuk menghegemoni masyarakat yang berada di bawah kekuasaannya. Adapun kedua cara tersebut ialah mengoptimalkan peranan Alquran dalam menyiarkan agama Islam, dan menunjukkan prinsip-prinsip Islam dalam menyebarkan agama Islam. ${ }^{15}$ Kedua prinsip inilah yang menjadi cara utama peradaban Islam dalam menghegemoni masyarakat yang ada di bawah kekuasaannya.

Jika dikatakan pada bab sebelumnya bahwasanya hegemoni ialah kepemimpinan yang terstruktur dan bermoral, maka kepemimpina peradaban Islam tersebut berada di tangan kepala pimpinan tertinggi. Adapun istilah kepala pimpinan tertinggi dalam peradaban Islam ialah Nabi, Khalifah, Malik, dan Sultan. Adapun moral yang digunakan dalam peradaban Islam ialah nilai-nilai Alquran dan prinsip-prinsip ajaran Islam.

Jika para orientalis menyebutkan bahwa peradaban islam merupakan peradaban yang miskin, maka pada bab ini penulis ingin memamparkan beberapa sumbangan dari hegemoni peradaban

${ }^{15}$ Ahmad Syalabi, Sejarah dan Kebudayaan Islam, cet ke-VI, Jilid 1,(Jakarta: Pustaka Al Husna, 1990), h. 313 
Islam yang diakui para Orientalis yang objektif dalam penelitian mereka. Sepanjang hegemoni peradaban Islam, setidaknya ada tiga sumbangan penting yang diberikan oleh peradaban Islam. Adapun ketiga sumbanga tersebut ialah: ${ }^{16}$

1. Sumbangan peradaban Islam dalam bidang ilmu pengetahuan

2. Sumbangan peradaban Islam dalam bidang Moral

3. Sumbangan peradaban Islam dalam bidang pemikiran.

Dalam bidang ilmu pengetahuan, hegemoni peradaban Islam memberikan sumbangan besar setidaknya pada beberapa disiplin ilmu sebagai berikut: kimia, ilmu psikologi, ilmu hitung, geologi, dan ilmuilmu sosial. ${ }^{17}$ Ada beberapa tokoh ilmuwan Islam yang sangat menonjol perannya dari beberapa bidang disiplin ilmu tersebut. Di antaranya ialah Ibnu al-Haitsam dan AlKhazin. Kedua tokoh ini sudah banyak diakui oleh orang-orang Eropa tentang tori dan riset mereka yang detil dalam ilmu pengetahuan alam modern. ${ }^{18}$ Bahkan, Gustave Le Bon dalam bukunya The Arab Civilization mengatakan bahwa buku-buku karya Jabir merupakan buku Ensiklopedi Kimia terlengkap dalam khazanah ilmu

\footnotetext{
${ }^{16}$ Raghib As Sirjani, Sumbangan Peradaban Islam pada Dunia, terj.Sonif, Masturi Ilham, \& Malik Sapar. Cet ke-IV, (Jakarata: Pustaka AlKautsar, 2015), h. 800

${ }^{17}$ Raghib As Sirjani, Sumbangan Peradaban Islam pada Dunia, hal.801.

${ }^{18}$ Ibid., h. 801.
}

kimia. $^{19}$

Kecemerlangan hegemoni peradaban Islam dalam bidang ilmu pengetahuan tidak lain tidak bukan karena kejelian para Ilmuwan Islam yang memadukan, mengembangkan, dan menginovasi ilmu pengetahuan yang berasal dari dua peradaban besar sebelum peradaban Islam, yaitu peradaban Byzantium (Romawi), dan peradaban Persia. $^{20}$

Selanjutnya, sumbangan hegemoni peradaban Islam yang kedua ialah pada bidang moral. Moral yang dihegemonikan dalam peradaban Islam merupakan moralmoral yang berasal dari nilai-nilai dan prinsip-prinsip Alquran. Karena Alquran merupakan kitab agama, ilmu, sosial, moral, akhlak, dan sejarah. Oleh karena moral yang dibawa oleh hegemoni Islam berasal dari Alquran, maka tentu moral yang ada dalam peradaban Islam berbeda dengan moral-moral yang ada pada peradaban-peradaban sebelum Islam. Di antara moral yang terdapat dalam peradaban Islam ialah keadilan, akhlak dan tauhid, menjunjung nilai-nilai toleransi, humanisme, dan persaudaraan global. ${ }^{21}$

${ }^{19}$ Gustave Le Bon, The Arab Civilization, terj. Adil Za'itur (Tanpa Kota: Isa al Babi al Halabi, tanpa tahun), h. 475

${ }^{20}$ Muhammad Karad Ali, al-Islam wa alHadharah al-'Arabiyah, cet ke-III, (Kairo: Lajnah at Ta'lif wa at Tarjamah wa an Nasyr, 1968), h. 231

${ }^{21}$ Abdul Mun'im an-Namr, al-Islam wa alMabadi' al-Mustauridah, (Kairo: Maktabah al Anjalu, 2004), h. 84 
Nilai keadilan yang ditunjukan oleh peradaban Islam benar-benar mampu menghegemoni masyarakat yang di bawah kekuasaan Islam. Sebagai contoh, kisah tentang pemimpin tertinggi umat Islam pada masa khulafaur rasyidin yang kedua, yaitu Umar bin Khattab. Suatu ketika Umar kehilangan pedangnya, dan dia menemukan pedangnya berada di bawa oleh seseorang dari kaum Yahudi. Umar pun melaporkannya kepada Hakim, akan tetapi karena Umar tidak memiliki saksi yang bersaksi bahwa pedang itu merupakan kepemilikan Umar. Maka, Hakim pun memberi keputusan bahwa pedang tersebut menjadi hak milik orang Yahudi tersebut. Hal ini tentu membuat orang Yahudi tersebut terharu, karena bagaimana mungkin sang Hakim memenangkan ia dalam persidangan tersebut, padahal ia hanyalah masyarakat rendah biasa, sedangkan musuhnya dalam persidangan itu ialah pemimpin tertinggi peradaban Islam saat itu. Hal ini tidak akan terjadi kecuali karena adanya nilai keadilan yang diterapkan dalam peradaban Islam saat itu. Nilai keadilan inilah yang menghegemoni yahudi tersebut sehingga dia mengembalikan pedang milik Umar, dan masuk Islam dengan sukarela. ${ }^{22}$

Moral yang tinggi dalam peradaban Islam juga diakui oleh Perdana Mentri India yang pertama, Jawaharlal Nehru. Ia

${ }^{22}$ Ahmad Syalabi, Sejarah dan Kebudayaan Islam, 331-332. mengatakan bahwa masuknya Islam ke India membawa moral-moral persamaan hak antara masyarakat yang nyata. Karena moral tersebutlah, pembagian kasta-kasta yang sudah mengakar pada masyarakat India pada umunya berhasil dihegemoni oleh moral Islam yang merangkul seluruh kasta yang ada paada system kasta masyarakat India. Sehingga, mayoritas umat India yang beragam Hindu pada saat itu dengan sukarela lebih memilih ajaran Islam dalam memandang persamaan hak dan derajat masyarakat. ${ }^{23}$

Hegemoni peradaban Islam di daerah yang mayoritas masyarakatnya memeluk agama selain agam Islam dilakukan dengan prinsip-prinsip toleransi yang terdapat dalam ajaran Islam. Bangsa mesir, Persia, Romawi, dan India yang saat itu merupakan negara yang berada di bawah kekuasaan Islam mengakui bahwa prinsip toleransi yang dibawa oleh peradaban Islam merupakan salah satu faktor utama mengapa mereka dengan sukarela memeluk agama Islam. $^{24}$ Kebebasan mereka beragama di bawah kekuasaan peradaban Islam inilah yang tidak mereka temui pada peradaban lain yang pernah mengekspansi mereka.

\footnotetext{
${ }^{23} \mathrm{Abu}$ al-Hasan an-Nadawi, Madza Khasara al-'Alam bi Inhithath al-Muslimin, (Kairo: Maktabah as Sunnah, 1990), h.107

${ }^{24}$ Gustave Le Bon, The Arab Civilization,
} 
Sumbangan hegemoni peradaban Islam yang terakhir ialah dalam bidang pemikiran. Meskipun banyak para orientalis yang beranggapan bahwa peradaban Islam merupakan peradaban yang tidak mengedepankan pemikiran dan rasionalitas, tetapi faktanya anjuran untuk berpikir sangat banyak ditemui dalam kitab suci umat Islam Alquran. Dan hal itu dibuktikan dengan hadirnya tokoh pemikir sekaligus filosof muslim yang keilmuwannya diakui oleh bangsa Eropa, yaitu Ibnu Rusyd. Averrous (panggilan Ibnu Rusyd oleh bangsa Eropa) merupakan ilmuwan yang paling berjasa dalam mengembalikan kebebasan berpikir di Eropa. Anjurannya untuk mengembalikan kebebasan berpikir dipaparkannya dalam penjelasan-penjelasannya atas beberapa karya Aristoteles. $^{25}$

Gerakan pemikiran yang mewarnai peradaban Islam bahkan diakui oleh Carra de Voux sebagai gerakan pemikiran yang mencapai level tertinggi, karena dalam gerakan pemikiran tersebut, para pemikir muslim menggunakan logika dan riset ilmiah yang objektif. ${ }^{26}$ Kemajuan peradaban Islam yang pesat dalam bidang pemikiran ini juga berdasarkan dari wahyu pertama Alquran yang menganjurkan manusia untuk membaca, dan memikirkan kekuasan Allah

${ }^{25}$ Atiyin Diniyah, Muhammad Rasulullah, terj. Abdul Halim Mahmud, (Beirut: Dar al Kitab al 'Arabi, 1985), h. 345

${ }^{26}$ Raghib as-Sirjani, Sumbangan Peradaban Islam pada Dunia, h. 813 yang ada dalam dirinya, dan dalam penciptaan alam semesta. Oleh karena hal itulah Maurice Bucaile mengibaratkan ajaran Islam dan ilmu pengetahuan bagaikan dua sisi mata uang logam yang tidak bisa dipisahkan. Karena anjuran untuk berilmu sudah ada sejak turunnya wahyu pertama Alquran. ${ }^{27}$

Kecemerlangan pemikiran dalam peradaban Islam bahkan diakui oleh Pangeran Charles saat memberikan pidato sambutan dalam acara bertajuk 'Islam dan Barat' di balai pusat Oxford. Ia mengatakan bahwa stigma negatif tentang peradaban Islam yang diberikan oleh sebagian bangsa Eropa saat ini jauh lebih sedikit daripada stigma positif yang diberikan oleh mayoritas bangsa Eropa tentang kecemerlangan pemikiran peradab Islam yang saat itu berpusat di Spanyol. Karena, bangsa Spanyol pada masa peradaban Islam, tidak hanya menjaga kandungan pemikiran dari peradaban Yunani dan Romawi, tetapi juga menafsirkan, bahkan mengembangkannya. Oleh karena itulah Spanyol yang saat itu (abad $\mathrm{X}$ Masehi) masih bernama Cordoba, merupakan kota yang paling memiliki peradaban yang cemerlang di antara kotakota Eropa lainnya. ${ }^{28}$

${ }^{27}$ Wahiduddin Khan, al-Islam Yatahadda, (Tanpa Kota: Muassasah ar Risalah, tanpa tahun), h. 14

${ }^{28}$ Raghib as-Sirjani, Sumbangan Peradaban Islam pada Dunia, h. 814-815 


\section{Kontribusi Peradaban Islam di Bidang Sastra Arab}

Kontribusi peradaban Islam di bidang Sastra Arab sangat tampak di kawasan Andalusia. Hal ini dibuktikan dengan pernyataan Abaniz (Penulis Andalusia) yang mengatakan bahwasanya para Penyair Andalusia tidak pernah mengekspresikan karya sastra mereka dalam tema kepahlawanan dan semangat perjuangan kecuali setelah peradaban Islam berkembang di negeri mereka. ${ }^{29}$ Hal ini menunjukan bahwa peradaban Islam berkontribusi pada karya satra di Andalusia, khususnya dalam hal tema-tema kepahlawanan dan semangat perjuangan.

Tidak hanya di Andalusia, kontribusi peradaban Islam dalam bidang Sastra Arab juga bahkan sampai ke beberapa daerah di Benua Eropa. Henry Maro berkata, bahwa sesungguhnya kontribusi peradaban Islam terhadap peradaban bangsa Romawi tidak terbatas pada bidang seni saja, melainkan juga pada bidang puisi. ${ }^{30}$ Hal ini dikuatkan dengan hadirnya karya Ibnu Hazm yang sangat terkenal pada masa itu, yaitu Thauq al-Hamamah.

Selain di ranah puisi, kontribusi peradaban Islam terhadap Eropa juga tampak di ranah Novel. Jika dianalisa lebih

\footnotetext{
${ }^{29}$ Mushthafa as-Siba'i, Min Rawa'I Hadharatina, (Kairo: Dar al-Waraq, 1998), h. 42

${ }^{30}$ Ahmad Darwis, Nazhariyyah al-Adab alMuqaran wa Tajliyatuha fi al-Adab al-'Arabi, (Kairo: Dar Gharib, 2002), h. 194-195
}

jeli, maka akan tampak sekali pengaruh Maqamat, kisah-kisah kepahlawanan, serta petualangan para jagoan dalam meraih cinta dan kehormatan dalam novel-novel bangsa Eropa. Adapun dua karya Sastra Arab yang sangat terkenal dan besar kontribusinya dalam karya Sastra Eropa ialah Alfu Lailah wa Lailah dan Hayy bin Yaqzhan. ${ }^{31}$

\section{Kesimpulan}

Konsep hegemoni Gramsci bekerja untuk menganalisa hegemoni yang ada dalam suatu pemerintahan. Dengan konsep ini, kelompok sosial bisa dikuasai melalui kepemimpinan yang terstruktur dengan cara yang lembut, dan bermoral. Pada awalnya konsep hegemoni ini menggunakan kelas proletar (buruh) sebagai objekya. Namun, Laclau dan Mouffe menginovasinya dengan menggunankan wacana (discourse) sebagai objek penelitian mereka berdua.

Hegemoni yang dikomandoi oleh peradaban Islam dilakukan melalui dua cara, yaitu dengan menyiarkan nilai-nilai Alquran, dan menyebarkan prinsip-prinsip ajaran Islam. Adapun sumbangan peradaban Islam yang juga diakui oleh para Orientalis mencakup tiga hal pokok, yaitu sumbangan hegemoni peradaban Islam

\footnotetext{
${ }^{31}$ Jack Rislar, Peradaban Arab, terj. Ghanim Abdun, (Tanpa Kota: ad-Dar alMisriyyah li Ta'lim wa Tarjamah, Tanpa Tahun), h. 223
} 
dalam bidang ilmu pengetahuan, dalam bidang moral, dan dalam bidang pemikiran.

Adapun kontribusi peradaban Islam dalam bidang Sastra Arab ialah hadirnya tema-tema kepahlawanan dan semangat perjuangan dalam karya sastra bangsa Andalusia khususnya dan bangsa eropa pada umumnya.

Tulisan ini hanya membahas hegemoni peradaban Islam dan kontribusi Islam pada peradaban dunia secara global. Tentunya hegemoni peradaban Islam dan kontribusi Islam pada peradaban dunia akan lebih lengkap dan lebih rinci bila ada yang mengkaji hegemoni peradaban Islam dan kontribusi Islam pada peradaban dunia di setiap bentuk sistem pemerintahan Islam, baik itu berupa system pemerintah khilafah, kerajaan, dan kesultanan.

\section{Daftar Pustaka}

an-Nadawi, Abu al-Hasan. Madza Khasara al-'Alam bi Inhithath al-Muslimin, Kairo: Maktabah as Sunnah, 1990.

an-Namr, Abdul Mun'im. al-Islam wa alMabadi' al-Mustauridah, Kairo: Maktabah al Anjalu, 2004.

as-Siba'I, Mushthafa. Min Rawa' $i$ Hadharatina, Kairo: Dar al-Waraq, 1998.

As Sirjani, Raghib. Sumbangan Peradaban Islam pada Dunia, terj.Sonif, Masturi Ilham, \& Malik Sapar. Cet ke-IV, (Jakarata: Pustaka Al-Kautsar, 2015)

Darwis, Ahmad. Nazhariyyah al-Adab alMuqaran wa Tajliyatuha fi al-Adab al'Arabi, Kairo: Dar Gharib, 2002.
Diniyah, Atiyin. Muhammad Rasulullah, terj. Abdul Halim Mahmud, Beirut: Dar al Kitab al 'Arabi, 1985.

Gramsci, Antonio, Selections From the Prison Notebooks, Quintin Hoare dan Nowell Smith (ed.) New York: International Publishers, 1976.

Karad Ali, Muhammad. al-Islam wa alHadharah al-'Arabiyah, cet ke-III, Kairo: Lajnah at Ta'lif wa at Tarjamah wa an Nasyr, 1968.

Khan, Wahiduddin. al-Islam Yatahadda, Tanpa Kota: Muassasah ar Risalah, tanpa tahun.

Laclau, Ernesto, "Democracy and the Question of Power", dalam Constellations Vol.8, No.1, 2001.

Laclau, Ernesto and Chantal Mouffe, Hegemony and Sosialist Strategy: Towards A Radical Democratic Politics, London: Verso, Second Edition, 2001.

Gustave Le Bon, The Arab Civilization, terj. Adil Za'itur, Tanpa Kota: Isa al Babi al Halabi, tanpa tahun.

Patria, Nezar dan Andi Arief, Antonio Gramsci Negara dan Hegemoni, Yogyakarta: Pustaka Pelajar, cet III, 2009.

Rislar, Jack. Peradaban Arab, terj. Ghanim Abdun, Tanpa Kota: ad-Dar al-Misriyyah li Ta'lim wa Tarjamah, Tanpa Tahun.

Said, Edward W. Orientalisme, terj. Achmad Fawid, Yogyakarta: Pustaka Pelajar, cet II, 2016.

Syalabi, Ahmad. Sejarah dan Kebudayaan Islam, cet ke-VI , Jilid I, Jakarta: Pustaka Al Husna, 1990.

Torfing, Jacob. New Theories of Discourse: Laclau, Mouffe, Zizek, Oxford: Blackwell, 1999. 
120 | II-Fathin Vol. 1 Edisi Juli-Desember 2018 